\title{
Trichoderma harzianum (Th-3) a Potential Strain to Manage the Purple Blotch of Onion (Allium cepa L.) Caused by Alternaria porri under North Indian Plains
}

\author{
V. Prakasam ${ }^{1} \&$ Pratibha Sharma ${ }^{1}$ \\ ${ }^{1}$ Division of Plant Pathology, Indian Agricultural Research Institute (IARI), New Delhi 110012, India \\ Correspondence: Dr. Pratibha Sharma, Professor, Division of Plant Pathology, Indian Agricultural Research \\ Institute, New Delhi 110012, India. Tel: 91-11-2584-8418; 91-981-011-9397. E-mail: pratibha@iari.res.in; \\ psharma032003@yahoo.co.in
}

Received: May 24, 2012 Accepted: June 13, 2012 Online Published: September 13, 2012

doi:10.5539/jas.v4n10p266 URL: http://dx.doi.org/10.5539/jas.v4n10p266

The research is sponsored by Indian Agricultural Research Institute (IARI), New Delhi 110012, India

\begin{abstract}
Purple blotch of onion by Alternaria porri (Ellis) Neerg. causes heavy yield loss in both bulb and seed crops. Using biocontrol agent to manage the disease is one of the most important approaches for successful disease management and sustainable onion production. For the development of bioagents based strategy seventeen isolates of fungal and six isolates of bacterial bioagents obtained from different sources were tested for their bioefficacy against $A$. porri. Effective isolates (Th-3, Th-30, Tv-12, Tv-15, Pf-3 and Bs-2) were selected and tested for volatile and non-volatile metabolites production and vigour induction under in vitro. Trichoderma harzianum isolate (Th-3) expressed high level of disease reduction and growth promotion in susceptible onion (cv. Pusa Red) when different methods viz., seed treatment, seedling dip and three foliar sprays were evaluated on onion bulb crop under glass house and field conditions. Field experiments (2008-2010) on onion seed crop also confirmed the potential of Th-3 isolate on disease suppression and growth promotion.
\end{abstract}

Keywords: Onion, Alternaria porri, Trichoderma harzianum, bioagents

\section{Introduction}

Onion is a vegetable crop of global importance and is known as protective food because of its special nutritive value. It also owns potent medicinal value in ayurvedic and homeopathic therapy. India ranks second in onion production after China. The area under onion cultivation was 4.78 lakh ha, with a production of 66.7 lakh mt. bulbs and having an average productivity of $10.38(\mathrm{t} / \mathrm{ha})$. Among the diseases, purple blotch caused Alternaria porri (Ellis) Neerg. is one of the destructive diseases, hence it causes frequent epidemic in most of the onion growing region of the country. Initial symptoms appear on leaves and inflorescence as small (2-3 $\mathrm{mm}$ in dia.) water soaked lesions that quickly develop purple centre with yellow margin under favorable conditions (Verma \& Sharma, 1999). The yield losses of bulb and seed crop in India due to this disease under favorable conditions are $96 \%$ (Gupta \& Pathak, 1998) and 97\% (Lokra, 1999), respectively. This disease has become a great menace to onion growers in India, which was confirmed by $70 \%$ of onion yield losses in Maharashtra by this pathogen during 2010 . Lack of resistant variety is one of the reasons for perpetuation of pathogen throughout the year and cause epidemic and farmers are forced to spray very high amount of pesticide on both onion bulb and seed crop. Due to health risk and pollution hazards by use of chemical fungicides in plant disease control, it is considered appropriate to minimize their use. Biological control of plant pathogens through antagonistic microorganisms is eco-friendly and a sustainable approach apart from the best alternative to the use of fungicides. Inhibitory effect of Trichoderma species viz., T. harzianum, T. pseudokoningii and T. virens on mycelial growth and spore germination of $A$. porri by using liquid cultural filtrates was extensively studied by (Imtiaj \& Lee, 2008; Tyagi et al., 1990) evaluated species of Penicillium, Aureobasidium pullulans, Sporobolomyces roseus and Crytococcus luteolus against Alternaria porri and found them effective in inhabiting growth of the pathogen. P. fluorescens (Pf1), Bacillus subtilis and T. viride were tested alone and in combination for suppression of onion leaf blight (Alternaria palandui) disease under glasshouse and field conditions. In addition to disease suppression, treatment with a 
mixture of antagonists promoted plant growth in terms of increased plant height and ultimately bulb yield (Karthikeyan et al., 2006). With this background, in the present investigation efficacy of antagonistic microorganisms in managing purple blotch in vitro and in vivo has been determined and the results are discussed.

\section{Materials and Methods}

Seeds and bulbs of onion (cv. Pusa Red) susceptible to Alternaria blight were obtained from the Division of Vegetable Science, IARI, New Delhi. The virulent isolate Alternaria porri isolated from the infected onion leaf samples from New Delhi region was used as test pathogen. Ten days old culture of $A$. porri was used in each experiment. Isolates of T. harzianum, T. viride, T. atroviridae, Pseudomonas fluorescens and Bacillus subtilis were obtained from Biocontrol laboratory and Cladosporium herborum was obtained from the Indian Type Culture Collection (ITCC), Division of Plant Pathology, IARI, New Delhi (Table 1).

Table 1. List of biocontrol agents used for in vitro screening against $A$. porri

\begin{tabular}{llll}
\hline S. No. & \multicolumn{1}{c}{ Bio-agents } & \multicolumn{1}{c}{ Isolates/Strains } & \multicolumn{1}{c}{ Sources } \\
\hline 1 & Trichoderma harzianum & Th-3, Th-8, Th-10, Th-17 \&Th-Ag & Soil \\
& & Th-7 & Rhizophere of cabbage \\
& & Th-30 & Rhizosphere of cauliflower \\
2 & Trichoderma viride & Tv-2,Tv-4 \& Tv-17 & Soil \\
& & Tv-12 & Phylloplane of ground nut \\
& & Tv-15 & Phylloplane of mustard \\
& & Tv-18 & Rhizosphere of wheat \\
& & Tv-32 & Rhizosphere of ground nut \\
3 & Trichoderma atroviridae & Tav-1 & Soil \\
4 & Cladosporium herbarum $*$ & Ch-1016 & Palm oil mill effluent \\
& & Ch-3137 & Crocus sativus \\
5 & Pseudomonas fluorescens & Pf -1 \& Pf -2 & Soil \\
& & Pf -3 & Phylloplane of soybean \\
& & Pf -4 & Phylloplane of mustard \\
6 & Bacillus subtilis & Bs-1 \& Bs-2 & Soil \\
\hline
\end{tabular}

*Isolates collected from Indian type cultural collection, others from Biocontrol lab, IARI, New Delhi.

Assay of biocontrol agents (BCAs) in vitro was conducted to select an effective biocontrol agents (BCAs) against A. porri, 17 fungal and six bacterial isolates were screened by dual culture method as described by Dennis and Webster (1971) using PDA medium. The PDA medium inoculated with the pathogen alone served as control. The inoculated plates were incubated at $27 \pm 1^{\circ} \mathrm{C}$ with three replications for seven days. Both antagonist and pathogen was measured when the test pathogen attained maximum radial growth in control treatment. Radial growths of $A$. porri isolate were recorded and percent inhibition was calculated using the formula (Vincent, 1927).

$$
\mathrm{I}=\frac{\mathrm{C}}{\mathrm{C}-\mathrm{I}} \times 100
$$

$\mathrm{I}=$ Percent growth inhibition, $\mathrm{C}=$ Colony diameter of pathogen in control, $\mathrm{T}=$ Colony diameter $/$ radial growth of pathogen in treatment.

The onion bulb crop trial was conducted during winters in 2008-09 at Glass house, Division of Plant Pathology, IARI, New Delhi. To evaluate the bioefficacy of BCAs viz., T. harzianum (Th-3 and Th-30) T. viride (Tv-12 and Tv-15), P. fluorescens (Pf-3) and B. subtilis (Bs-1) were selected based on dual culture method and mode of action was confirmed to volatile and non-volatile compounds production (Pandey \& Upadhyay, 1997). Onion seeds (cv. Pusa Red)were treated @ $2 \times 10^{10}$ spore suspension per ml for fungal and $2 \times 10^{9} \mathrm{cfu}$ for bacterial bioagents for half an hour and shade dried for two hours. Seeds treated with mancozeb75 EC @ $0.25 \%$ were used for comparison and sterile water used as a control. The treated seeds were sown in pots. The same treatments were followed for 60 days old seedlings for root dipping. For foliar application the liquid formulation (developed in Biocontrol Laboratory) was sprayed on 45, 55 and 65 days after transplanting and challenge inoculation with spray A. porri were done two days after first spray of bioagents. The purple blotch incidence and intensity were recorded at 30 days after first BCAs spray. 
The field trials were conducted to determine the effectiveness of the above mentioned BCAs. The onion bulb crop trial was conducted during winters in 2008-09 at Experimental field, Division of Plant Pathology, IARI, New Delhi. The treatments were followed as in glass house trial. Treated seedlings were planted with $20 \times 10 \mathrm{~cm}$ spacing in the plots size of $2 \times 3 \mathrm{~m}^{2}$. The onion seed crop trial was conducted during winters in 2009-10 at seed production unit, Division of Vegetable Science, IARI, New Delhi where this disease is endemic in nature as monoculturing of this crop facilitated continuous survival of $A$. porri in the form of spores and dormant mycelium in plant debris and soil. The onion bulb was treated with BCAs followed by three foliar sprays of BCAs at ten day intervals 130 days after planting. The treated bulbs were in plot size of $1.5 \times 5 \mathrm{~m}^{2}$ with the spacing of $75 \times 60 \mathrm{~cm}$. The purple blotch intensity and incidence were recorded 30 days after first spray of the BCAs described earlier. The disease severity was measured by using 0-5 rating scale and incidence was expressed in percentage (Borker \& Patil, 1993).

The standard statistical method used in in vitro studies was Completely Randomized Design (CRD). The field experiments were laid out in Randomized Block Design (RBD) with 8 treatments including controls and replicated 3 times. The plot size was $2 \times 6 \mathrm{sq} \mathrm{m}$ and $1.5 \times 6 \mathrm{sq} \mathrm{m}$ onion bulb and seed crop, respectively.

\section{Results}

\subsection{Effects of Antagonist on Radial Growth of the Pathogen}

To screen out the effective bioagents against $A$. porri, 17 fungal and six bacterial BCAs were tested by using dual culture technique in in-vitro. Almost all BCAs inhibited the mycelial growth of the pathogen significantly over control (Table 2) T. harzianum (Th-3) inhibited the growth of pathogen upto 61.5 per cent which was significantly superior to all other isolates, followed by the other Trichoderma isolates Tv-12 (56\%), Th-30 (53\%) and Tv-15 (52\%), while C. herbarum (Ch-1016) 15\% showed the lowest inhibition. Among the bacterial strains $P$. fluorescens (Pf-3) showed highest inhibition growth of $49 \%$ followed by B. subtilis Bs-1 (48\%) on A. porri, while Bs-2 (33\%) showed the lowest inhibition (Figure 2). The bioefficacy of T. harzianum (Th-3 and Th-30), T. viride (Tv-12 and Tv-15), Pseudomonas fluorescence (Pf-3) and Bacillus subtilis (BS-1) was confirmed with volatile and non-volatile compound production. In vitro study showed that Cladosporium herbarum was not effective against A. porri thus, contradicting the report of $66.6 \%$ reduction in A. porri infection with cladosporium herbarum associated with the phyllosphere of the onion plant (Tyagi et al., 1990). The Trichoderma species revealed the pathogen on PDA medium may be through diffusible antibiotics production, mycoparasitism, siderophore formation (Park, 1960). Protease and fungal cell wall degrading enzymes make the fungi an attractive biocontrol agent (Dennis \& Webster, 1971; Elad, 2000).

Table 2. Mode of action of isolates of fungal antagonist against $A$. porri

\begin{tabular}{ccccl}
\hline S.No. & $\begin{array}{c}\text { Name of fungal } \\
\text { antagonist }\end{array}$ & $\begin{array}{c}\text { Radial growth of } \\
\text { pathogen }(\mathbf{m m})\end{array}$ & $\begin{array}{c}\text { Percent inhibition } \\
\text { over control }\end{array}$ & Mode of action \\
\hline 1 & Th-3 & 15.33 & 61.54 & Inhibition \\
2 & Th-7 & 31.00 & 22.25 & Mycelial over growth \\
3 & Th-8 & 29.00 & 27.27 & Mycelial over growth \\
4 & Th-10 & 32.00 & 19.74 & Inhibition \\
5 & Th-17 & 28.00 & 29.77 & Mycelial over growth \\
6 & Th-30 & 18.67 & 53.20 & Inhibition \\
7 & Th-Ag & 22.67 & 43.15 & Inhibitiom \\
8 & Tv-2 & 32.33 & 18.91 & Inhibition \\
9 & Tv-4 & 24.67 & 38.15 & Inhibition \\
10 & Tv-12 & 17.67 & 55.71 & Inhibition \\
11 & Tv-15 & 19.33 & 51.51 & Mycelial over growth \\
12 & Tv-17 & 23.66 & 40.66 & Inhibition \\
13 & Tv-18 & 27.00 & 32.28 & Mycelial over growth \\
14 & Tv-32 & 29.00 & 27.27 & Inhibition \\
15 & Av-1 & 32.33 & 18.91 & Mycelial over growth \\
16 & Ch-1016 & 34.00 & 14.73 & Mycelial over growth \\
17 & Ch-3137 & 27.00 & 32.27 & Mycelial over growth \\
18 & Control & 39.87 & - & \\
\hline
\end{tabular}


Table 3. Mode of action of isolates of bacterial antagonist against $A$. porri

\begin{tabular}{ccccc}
\hline S.No. & $\begin{array}{c}\text { Name of bacterial } \\
\text { antagonist }\end{array}$ & $\begin{array}{c}\text { Radial growth of } \\
\text { pathogen }(\mathbf{m m})\end{array}$ & $\begin{array}{c}\text { Percent inhibition } \\
\text { over control }\end{array}$ & Mode of action \\
\hline 1 & Pf-1 & 24.67 & 35.85 & Inhibition \\
2 & Pf-2 & 23.00 & 40.18 & Inhibition \\
3 & Pf-3 & 19.67 & 48.86 & Inhibition \\
4 & Pf-4 & 24.00 & 37.58 & Inhibition \\
5 & Bs-1 & 20.00 & 47.93 & Inhibition \\
6 & Bs-2 & 25.67 & 33.45 & Inhibition \\
7 & Control & 38.45 & ------ & \\
\hline
\end{tabular}

\subsection{Glass House Trial}

The six BCAs (Th-2, Th-30, Tv-12, Tv-15, Pf-3 and Bs-2) were studied against purple blotch disease in pot culture under glass house conditions. The bulb onion crop result revealed that the Th- 3 treatment showed lesser disease severity of $13.3 \%$ as against $41.4 \%$ disease incidence in control. The next best treatment was Pf-3 (17.8\%) followed by Tv-15 (18.2\%). Isolate Th-3 also induced the plant growth parameters such as number of leaves and plant height followed by other isolates (Table 4). Onion seed germination and growth of onion seedlings by stimulation of growth may be due to regulators such as IAA (Glick et al., 1998).

Table 4. Effect of bioagents against $A$. porri in onion bulb crop under glass house conditions during 2007-08

\begin{tabular}{|c|c|c|c|c|c|}
\hline \multirow[b]{2}{*}{ S.No. } & \multirow[b]{2}{*}{ Treatments } & \multicolumn{2}{|c|}{ Plant disease incidence } & \multicolumn{2}{|c|}{ Plant growth promotion } \\
\hline & & $\begin{array}{l}\text { Per cent disease index } \\
\text { (PDI) }\end{array}$ & $\begin{array}{c}\text { Disease } \\
\text { reduction over } \\
\text { control }(\%)\end{array}$ & $\begin{array}{c}\text { Number of } \\
\text { leaves }\end{array}$ & $\begin{array}{l}\text { Plant height } \\
\text { (cm) }\end{array}$ \\
\hline 1 & Th-3 & $13.37 \quad(22.25)$ & 67.66 & 12.4 & 54.00 \\
\hline 2 & Th-30 & $26.60 \quad(31.00)$ & 35.64 & 9.4 & 39.40 \\
\hline 3 & $\mathrm{Tv}-12$ & $21.18 \quad(27.38)$ & 48.78 & 9.4 & 46.60 \\
\hline 4 & Tv-15 & $18.19 \quad(26.69)$ & 56.15 & 8.8 & 48.20 \\
\hline 5 & Pf-3 & $17.79 \quad(25.68)$ & 57.04 & 9.6 & 44.60 \\
\hline 6 & Bs-1 & $19.32(26.06)$ & 53.28 & 10.0 & 49.40 \\
\hline 7 & Mancozeb & $11.28 \quad(19.49)$ & 72.72 & 7.0 & 42.00 \\
\hline \multirow[t]{2}{*}{8} & Control & $41.36(34.61)$ & - & 6.0 & 36.60 \\
\hline & $\mathrm{CD}(0.05)$ & $(3.75)$ & & 2.83 & 6.53 \\
\hline
\end{tabular}

*Value in the parenthesis is arc sin transformed.

\subsection{Field Trial on Onion Bulb Crop}

Experimental results on onion bulb crop indicated that the liquid based formulation of BCAs (Th-3, Th-30, Tv-12, Tv-15, Pf-3 and Bs-2) significantly reduced the leaf blight incidence. The magnitude of disease reduction varied between $64.8 \%$ (Th-3) and $27.1 \%$ (Th-30) among the bioagents (Table 4). The highest disease reduction was observed in seed treatment, seedling dip and $0.25 \%$ spray of mancozeb75 EC after disease incidence. However, among BCAs treatment the highest disease reduction (64.8\%) was noticed in seed treatment, seedling dip and three foliar spray of Th-3 isolate and followed by Tv-15 (52.8). The ancillary characters like number of leaves, plant height bulb diameter were increased and ultimately yield (10.23 tons/acre) was increased over control plot (7.65tons/acre) (Table 6). It indicated that Th-3 has protective as well as growth promoting activity to the onion growth and bulb development. Bioagents such as Chaetomium globosum, T. harzianum, T. koningii and Fusarium 
sp. increased the number of healthy plants in both radish samples tested, against A. raphani and A. brassicicola disease (Vannacci \& Harman, 1987).

\subsection{Field Trial on Onion Seed Crop}

To validate the effect of BCAs on onion bulb crop under glass house and field conditions, studies were applied to onion seed crop through bulb treatment and foliar spray of BCAs. Disease incidence in T. harzianum (Th-3) treated plots was very less $(27.36 \%)$ compared with all other treatments but lower than Mancozeb 75 EC $(0.25 \%)$ treated plants $(15.2 \%)$. The percent plant disease reduction by the bioagent tested was between 78.3 and 52.7 (Table 5). Plants treated with Th-3 showed significant difference among other treatments with respect to number of leaves, plant height, and seed weight per plant at $42.2 \mathrm{~g}$ over control at $30.6 \mathrm{~g}$ and seed yield $210.2 \mathrm{~kg} /$ acre over control plot at $152.9 \mathrm{~kg} / \mathrm{acre}$; even though Th-3 showed low disease reduction $(61.0 \%)$ potential than mancozeb (78.4\%). It indicated that $T$. harzianum (Th-3) isolate not only suppress the pathogen infection and invasion but also induced the growth and yield parameter in onion seed crop.

Table 5. Effect of bioagents against purple blotch of onion bulb crop under field conditions during 2008-09

\begin{tabular}{|c|c|c|c|c|c|c|c|c|}
\hline \multirow[b]{2}{*}{ S.No } & \multirow[b]{2}{*}{ Treatments } & \multicolumn{2}{|c|}{ Plant disease incidence } & \multicolumn{5}{|c|}{ Plant growth and yield promotion } \\
\hline & & $\begin{array}{c}\text { Percent } \\
\text { disease index } \\
\text { (PDI) }\end{array}$ & $\begin{array}{c}\text { Disease reduction } \\
\text { over control (\%) }\end{array}$ & $\begin{array}{l}\text { Number } \\
\text { of leaves }\end{array}$ & $\begin{array}{c}\text { Plant } \\
\text { height } \\
(\mathrm{cm})\end{array}$ & $\begin{array}{l}\text { Diameter } \\
\text { of bulb } \\
(\mathbf{m m})\end{array}$ & $\begin{array}{l}\text { Yield/plot } \\
(6 \mathrm{sq} \mathrm{m}) \text { in } \\
\mathrm{kg}\end{array}$ & $\begin{array}{l}\text { Bulb yield } \\
\text { (tons/acre) }\end{array}$ \\
\hline 1 & Th-3 & $18.17(25.19)$ & 64.77 & 8 & 59.6 & 75.25 & 15.35 & 10.23 \\
\hline 2 & Th-30 & $37.59(37.81)$ & 27.10 & 6.4 & 44.8 & 57.37 & 9.37 & 6.25 \\
\hline 3 & Tv-12 & $30.28(33.38)$ & 41.29 & 6.8 & 54.0 & 68.87 & 13.12 & 8.75 \\
\hline 4 & Tv-15 & $24.32(29.51)$ & 52.84 & 7.6 & 56.2 & 71.12 & 14.47 & 9.65 \\
\hline 5 & Pf-3 & $30.75(33.68)$ & 40.37 & 7.2 & 44.6 & 63.00 & 11.62 & 7.74 \\
\hline 6 & Bs-1 & $27.31(31.50)$ & 47.04 & 7.4 & 55.6 & 68.50 & 13.59 & 9.06 \\
\hline 7 & Mancozeb & $11.70(23.14)$ & 77.31 & 7.4 & 44.8 & 66.00 & 12.00 & 8.00 \\
\hline 8 & Control & $51.58(45.91)$ & - & 6.8 & 41.2 & 59.50 & 11.47 & 7.65 \\
\hline \multicolumn{2}{|c|}{$\mathrm{CD}(P=0.05)$} & $(4.31)$ & & NS & 7.39 & 3.896 & 1.7 & \\
\hline
\end{tabular}

*Value in the parenthesis is arc sin transformed.

Table 6. Effect of biocontrol agents against purple blotch of onion seed crop under field conditions during 2009-10

\begin{tabular}{cccccccc}
\hline & & \multicolumn{2}{c}{ Plant disease incidence } & \multicolumn{4}{c}{ Plant growth and yield promotion } \\
\cline { 3 - 7 } S.No & Treatments & $\begin{array}{c}\text { Percent } \\
\text { disease index } \\
\text { (PDI) }\end{array}$ & $\begin{array}{c}\text { Disease } \\
\text { reduction } \\
\text { over control }\end{array}$ & $\begin{array}{c}\text { Number of } \\
\text { flowering } \\
\text { stock }\end{array}$ & $\begin{array}{c}\text { Flowering } \\
\text { stalks height } \\
\text { (cm) }\end{array}$ & $\begin{array}{c}\text { Average } \\
\text { weight per plant } \\
\text { (gms) }\end{array}$ & $\begin{array}{c}\text { Seed yield } \\
\text { (kg/acre) }\end{array}$ \\
\hline 1 & Th-3 & $27.36(30.34)$ & 61.06 & 12.90 & 120.83 & 42.16 & 210.20 \\
2 & Th-30 & $33.19(35.16)$ & 52.76 & 8.067 & 103.50 & 35.42 & 177.10 \\
3 & Tv-12 & $30.90(33.43)$ & 56.02 & 10.60 & 109.90 & 38.28 & 191.40 \\
4 & Tv-15 & $29.30(30.83)$ & 59.30 & 11.53 & 115.97 & 39.76 & 198.00 \\
5 & Pf-3 & $33.14(33.29)$ & 52.83 & 10.00 & 110.90 & 34.61 & 172.80 \\
6 & Bs-1 & $28.48(32.20)$ & 58.41 & 10.30 & 114.97 & 38.35 & 191.75 \\
7 & Mancozeb & $15.20(25.20)$ & 78.36 & 10.97 & 114.23 & 36.36 & 181.80 \\
8 & Control & $70.27(57.01)$ & - & 8.50 & 97.17 & 30.59 & 152.95 \\
\hline CD $(P=0.05)$ & $(3.77)$ & & 0.93 & 9.13 & 2.57 & \\
\hline
\end{tabular}

*Value in the parenthesis is arc sin transform

\section{Discussion}

Effects of biocontrol agents on onion bulb crop were studied under glasshouse (2007-08) and field condition (2008-09) and (2009-10) field trials on onion seed crop found that disease reduction was higher in Th-3 treated plate. This showed that T. harzianum (Th-3) was most effective biocontrol strain when compared to others such as Th-30, Tv-12, Tv-15, Pf-3 and Bs-1, which was next to fungicide Mancozeb 75 EC at $0.25 \%$. In addition to the suppression of diseases the antagonistic treatment greatly induces plant growth. The present study on onion bulb 
crop and seed crop glasshouse as well as field condition showed that Th-3 increased the growth and yield parameter such as bulb and seed. Our experimental results were more similar to that of Coskutuna and Ozer (2008). Researcher revealed that $T$. harzianum decreased the onion basal rot caused by Fusarium oxysporum $f$. cepae comparable to fungicide in both pot and field experiments. Authors also reported that bulb diameter was increased and found presence of anti-fungal compounds on onion bulb grown from Trichoderma treatment by chromatography. The diversity of mechanism available to Trichoderma sp for pathogen suppression through broad range of antifungal metabolites production, mycoparasitism, competition with pathogen of nutrient and occupation of infection court, induced resistance (Elad, 2000). Imtiaz and Lee (2008) reported that T. virens was most effective against A.porri in in vivo compare to other fungal BCAs but in our results $T$. horzianum showed potential bio-control activity against $A$. porri when compared to fungal and bacterial BCAs used for present study. Seed treatment with $T$. harzianum-22, T. harzianum-50, increased emergence and improved health of the seedlings, and the antagonistic effect of these T. harzianm on A. brassicicola on seed coats and seedling roots of cabbage was also proved by Wu and $\mathrm{Lu}$ (1984). Meena et al. (2004) identified a natural tool, that is isolate of T.harzianum could be ecofriendly viable substitutes for chemical fungicide mancozeb in management of Alternaria blight of mustard. $T$. harzianum (T-39) living cells applied to the roots and dead cells applied to the leaves of cucumber plants controls the foliar pathogens such as Botrytis cinerea, Pseudoperonospora cubensis, Sclerotinia sclerotiorum and Sphaerotheca fusca under commercial greenhouse conditions (Elad, 2000). Many recent studies have been demonstrated the effect of T. harzimum on post harvest diseases which cause fruit rot, for example, significant curative and preventive effect was provided by the antagonistic strain Th- 1 of $T$. harzianum against $A$. alternata causing black fruit spot on persimmon fruits (Batta, 2004).The efficacy of T. harzianum isolate Th- 3 has been most extensively studied on horticulture crops such as cauliflower, cabbage, onion, garlic, chilly, rose and gladiolus against a large number of foliar and soil borne fungi such as Pythium aphanidermatum, Sclerotinia spp, Rhizoctonia solani, Colletotrichum spp and Alternaria spp. under in vitro and field condition different agro-climatic regions (Northern plain, Western and North western) (Sharma \& Sain, 2005; Sharma et al., 2005; Sharma et al., 2004; Sharma et al., 2001).

Results of the present study revealed the potential of Th- 3 in increasing growth and development of onion bulb and seed crop. It effectively suppresses the disease of purple blotch on onion leaf and flower stalk caused by $A$. porri. Use Th-3 could be promoted as an active component of bio-intensive integrated pest management programme in Chilli (Sharma et al., 2004). This would increase the success rate of these potential candidates for plant growth promotion and biocontrol activity much to the relevance of agriculturally dependent organic studies.

The current study assures the efficiency of T. harzianum (Th-3) as a potential biocontrol agent against $A$. porri pathogen and indicates the need of production and development of T. harzianum (Th-3) based BCAs to serve as model for environment friendly biocontrol agent. Th-3 effectively managed the pathogen and simultaneously increased the growth of plants and proved as yield increase in both onion bulb and seed crop. These experimental findings could be very useful to North and North Western plain of India where onion bulb and seed crop is more prevalent and also where ever purple blotch disease is endemic in nature and a menace to commercial seed production.

\section{Acknowledgements}

The authors are sincerely thankful to Dr. Subodh Joshi, Professor, Division of Vegetable Science, Indian Agricultural Research Institute, for providing field to conduct onion seed crop experiment. The first author is thankful to Indian Agricultural Research Institute for granting Senior Research Fellowship during Ph. D programme (2006-2010).

\section{References}

Batta, Y. A. (2004). Postharvest biological control of apple gray mold by Trichoderma harzianum (Rifai) formulated in invents emulsion. Crop Protection, 23, 19-26.

Borkar, S. G., \& Patil, B. S. (1993). Chemical control of purple blotch of onion. Indian Journal of Mycology and Plant Pathology, 25, 288-289.

Coskuntuna, A., \& Ozer, N. (2008). Biological control of onion basal rot diseases using Trichoderma harzianum and induction of antifungal compounds in onion set following seed treatment. Crop Protection, 27, 330-336. http://dx.doi.org/10.1016/j.cropro.2007.06.00

Dennis, C., \& Webster, J. (1971). Antagonastic properties of species group of Trichoderma-II. Production of volatile antibiotics. Transaction of the British Mycological Society, 57, 41-43. http://dx.doi.org/10.1016/S0007-1536(71)80078-5 
Elad, Y. (2000). Biological control of foliar pathogens by means of Trichoderma harzianum and potential modes of action. Crop Protection, 19, 709-714. http://dx.doi.org/10.1016/S0261-2194(00)00094-6

Glick, B. R., Penrose, D. M., \& Li, J. (1998). A model for lowering of plant ethylene concentration by plant growth promoting bacteria. Journal Theoratical Biology, 190, 63-68. http://dx.doi.org/10.1006/jtbi.1997.0532

Gupta, R. B. L., \& Pathak, V. N. (1998). Yield loss in onion due to purple blotch disease caused by Alternaria porri. Phytophylactica, 20, 21-23.

Imtiaj, A., \& Tae, L. (2008). Antagonistic effect of three Trichoderma species on the Alternaria porri Pathogen of onion Blotch. World Journal of Agricultural Science, 4, 13-17.

Karthikeyan, M. R., Bhaskaran, K., Radhika, S., Mathiyazhagan, D., Alice, R., Sandosskumar, \& Velazhahan, R. (2006). Biological control of leaf blight of onion by use of oil formulations. Indian Journal of Plant Protection, 34(1), 89-93.

Lokra, B. S. (1999). Development of purple blotch incited by Alternaria porri and its losses in seed crop of onion (Allium cepa). Indian Journal of Agricultural Sciences, 69, 144-146.

Meena, P. D., Meena, R. L., Chattopadhyay, C., \& Kumar, A. (2004). Identification of crucial stage for disease development and biocontrol of Alternaria blight of Indian mustard. Journal of Phytopathology, 152, 204-209. http://dx.doi.org/ 10.1111/j.1439-0434.2004.00828.x

Nene, Y. L., \& Thapliyal, P. M. (1971). Fungicides in plant disease control. Oxford and IBH publishing Co, Pvt. Ltd. New Delhi.

Pandey, K. K., \& Upadhyay, J. P. (1997). Selection of potential biocontrol agents based on production of volatile and non-volatile antibiotics. Vegetable Science, 24, 144-146.

Park, D. (1960). Antagonism, the background to soil fungi. In: The Ecology of Soil Fungi. D. Parkinson and J.S. Waid (eds.) Liverpool University Press, pp. 148-159.

Promotkumar, T., \& Palakshappa, M. G. (2008). Management of purple blotch of onion through bioagents. Karnataka. Journal Agricultural Sciences, 21(2), 306-388.

Sharma, P., \& Sain, S. K. (2005). Use of biotic agents and abiotic compound against damping of cauliflower caused by Pythium aphanidermatum. Indian Phytopahology, 58(4), 395-401.

Sharma, P., Kadu, L. N., \& Sain, S. K. (2005). Biological management of dieback and fruit rot of chilli caused by Colletotrichum capsici (Syd.) Butler and Bisby. Indian Journal of Plant Protection, 33, 226-230.

Sharma, P., Kulshrestha, G., Gopal, M., \& Kadu, L. N. (2004). Integrated Management of Chilli Die Back and Anthracnose in Delhi Region. Indian Phytopathology, 57, 427-434.

Sharma, P., Singh, L., \& Adlakha, D. (2001). Antagonistic potential of Trichoderma and Aspergillus species on Sclerotinia sclerotiorum (Lib.) de Bary causing rots in cabbage and cauliflower. Pesticides Information, 2, 41.

Srivastava, K. J., \& Gupta, R. P. (2006). Disease of onion and Garlic, NHRDF, Nasik.

Tyagi, S., Dubey, V. P., \& Charya, M. U. (1990). Biological control of Purple blotch of onion caused by A. porri (Ellis.) ciferri, Tropical Pest Management, 36, 384-386.

Vannacci, G., \& Harman, G. E. (1987). Biocontrol of seed-borne Alternaria raphani and A. brassicicola. Canadian Journal of Microbiology, 33(10), 850-856. http://dx.doi.org/ 10.1139/m87-149

Verma, L. R., \& Sharma, R. C. (1999). Diseases of horticultural crops vegetables, ornamentals and mushrooms. Indus Publishing Company, New Delhi, 353-356.

Vincent, J. M. (1927). Distortion of fungal hyphae in the presence of certain inhibitors. Nature, 159, 850. http://dx.doi.org/10.1038/159850b0

Wu, W. S., \& Lu, J. H. (1984). Seed treatment with antagonists and chemicals to control Alternaria brassicicola. Seed Science and Technology, 12, 851-862. 